\title{
Conjunctival Foreign Body
}

National Cancer Institute

\section{Source}

National Cancer Institute. Conjunctival Foreign Body. NCI Thesaurus. Code C118740.

External material in or on the conjunctiva. 